\title{
Evaluation of ultrasound-guided fine needle aspiration biopsy (USG-FNAB) of thyroid nodules: 12 years of accepted diagnostic algorithm in Holycross Cancer Centre (HCC) in Kielce
}

\author{
Jacek Sygut ${ }^{1 *}$, Aldona Kowalska², Janusz Słuszniak ${ }^{3}$, Jacek Heciak ${ }^{4}$ Janusz Kopczyński ${ }^{1}$, Dominik Sygut ${ }^{5}$, \\ Kornelia Niemyska', Stanisław Góźdź ${ }^{6}$
}

From 4th Congress of the Polish Thyroid Association 2013

Lodz, Poland. 11-13 April 2013

\section{Introduction}

Role and place of USG-FNAB in diagnosis of thyroid lesions were confirmed in recently published algorithm proposed by the recommendations of Polish Group of Endocrine Tumours.

\section{Aim of the study}

Presentation of parameters describing thyroid USGFNAB in HCC in Kielce.

\section{Material}

Since year 2000 all FNABs, including thyroid gland, were performed and evaluated according to the accepted diagnostic algorithm. Between 2001 and 2012 FNAB was performed for 26361 patients, in 28079 biopsy sessions with 40815 ultrasonographically selected and biopsied thyroid lesions. Since year 2001, all data about subsequently surgically treated patients along with pathology reports and with previous FNAB data were currently gathered. Each correlated case gained true positive (TP), true negative $(\mathrm{TN})$, false positive (FP) or false negative (FN) status. There were overall 1453 cases of thyroid malignancies of all 10142 correlated FNABs vs. subsequent surgical specimens in CORRELATION DATABASE between 2001-2012. In that period of time there were $343 \mathrm{TP}, 1026 \mathrm{TN}, 3 \mathrm{FP}$ and 74 FN correlated cases of thyroid malignancies. On the basis of these data, sensitivity, specificity and overall accuracy for thyroid USGFNAB were calculated.

\footnotetext{
${ }^{1}$ Pathology Department, Holycross Cancer Centre in Kielce, Kielce, Poland
} Full list of author information is available at the end of the article

\section{Methods}

On the basis of annual data for true and false cases, overall sensitivity (OS), overall specificity (OSP) and overall accuracy (OA) were estimated. The trend for those values was evaluated.

\section{Results}

For whole analyzed period of time (2001-2012) FNAB's OS was 0.85 , ranging from 0.68 to 1.0 and OSP was 1.0, ranging from 0.97 to 1.0 . OA was 0.95 , ranging from 0.9 to 1.0. In graphical analysis there was a strong gradual trend of increase in sensitivity since year 2007, with maintaining specificity approaching 1.0. Statistically significant strong positive trend of sensitivity value $(\mathrm{R}=0.76, \mathrm{p}=0.004)$ was shown for each year, separately from the flow of time, in analyzed period of time.

\section{Conclusions}

Applied in our department USG-FNAB method was characterized by statistically significant and regular increase of correct malignant tumour diagnoses (sensitivity) and overall accuracy with stable high level of correct benign lesions diagnoses (specificity).

\footnotetext{
Author details

${ }^{1}$ Pathology Department, Holycross Cancer Centre in Kielce, Kielce, Poland. ${ }^{2}$ Endocrinology Department, Holycross Cancer Centre in Kielce, Kielce, Poland. ${ }^{3}$ Oncological Surgery Department, Holycross Cancer Centre in Kielce, Kielce, Poland. ${ }^{4}$ Radiology and Imaging Diagnostics Department, Holycross Cancer Centre in Kielce, Kielce, Poland. ${ }^{5}$ Pathology Department, Medical University of Lodz, Lodz, Poland. 'Holycross Cancer Centre Board, Kielce, Poland.
} 
doi:10.1186/1756-6614-6-S2-A58

Cite this article as: Sygut et al.: Evaluation of ultrasound-guided fine needle aspiration biopsy (USG-FNAB) of thyroid nodules: 12 years of accepted diagnostic algorithm in Holycross Cancer Centre (HCC) in Kielce. Thyroid Research 2013 6(Suppl 2):A58.

Submit your next manuscript to BioMed Central and take full advantage of:

- Convenient online submission

- Thorough peer review

- No space constraints or color figure charges

- Immediate publication on acceptance

- Inclusion in PubMed, CAS, Scopus and Google Scholar

- Research which is freely available for redistribution

Submit your manuscript at www.biomedcentral.com/submit
C Biomed Central 